\title{
ALTERNATIVE DESIGN AND ECONOMIC FEASIBILITY OF AN EXPERIMENTAL WHR FOR INTAKE AIR CONDITIONING OF A LARGE INTERNAL COMBUSTION ENGINE
}

\author{
V. B. Paula, \\ A. Chun, \\ B. M. Miotto, \\ C. C. M. Cunha, \\ J. L. M. Donatelli, \\ and J. J. C. S. Santos \\ Universidade Federal do Espírito Santo \\ Centro Tecnológico \\ Bairro Goiabeiras \\ CP. 29075-910, Vitória, Espírito Santo, Brasil \\ vitor.buson@gmail.com \\ andr.chun@gmail.com \\ brunomiotto77@hotmail.com \\ carla@ele.ufes.br \\ donatelliufes@gmail.com \\ jjcssantos@yahoo.com.br \\ Received: Dec 07, 2020 \\ Revised: Dec 17, 2020 \\ Accepted: Dec 18, 2020
}

\section{ABSTRACT}

This work presents an alternative design for an experimental waste heat recovery thermal system to be coupled to a large turbocharged internal combustion engine for combustion air conditioning. The goal is to carry out a design of a new thermal system under restricted economic requirements for one of the generators set of Luiz Oscar Rodrigues de Melo Thermoelectric Power Plant. Thereby, a comparison with the original proposal from previous works is also developed in order to demonstrate the differences in terms of thermoeconomic design parameters. The waste recovery thermal system produces sufficient chilled water through a single-effect absorption chiller, powered by hot water which is produced by recovering the exhaust gases residual heat to supply cooling applications on the combustion air. The results showed a significant reduction for the chiller capacity demand, from 550 to $185 \mathrm{RT}$, that would be enough to provide chilled water for $98.72 \%$ of the analyzed operation historical period. The economic feasibility indicators reveal the proposal for the alternative waste heat recovery system as the best financial option, presenting a lower investment cost (US\$316,793.27 of savings) and a time for capital recovery of 2.14 years, 1.61 years shorter when compared with the initial WHR system.

Keywords: waste heat recovery; internal combustion engine; absorption chiller; intake air conditioning; economic feasibility

\section{NOMENCLATURE}

A heat flow area, $m^{2}$

$G \quad$ local gravity acceleration, $\mathrm{m} / \mathrm{s}^{2}$

$h \quad$ enthalpy, $\mathrm{kJ} / \mathrm{kg}$

$H$ head, $m$

$\dot{\mathrm{m}}$ mass flow rate, $\mathrm{kg} / \mathrm{s}$

$\dot{Q} \quad$ heat flow rate, $\mathrm{kJ} / \mathrm{s}$

$Q \quad$ volume flow, $\mathrm{m}^{3} / \mathrm{s}$

$U$ overall heat transfer coefficient, $W / \mathrm{m}^{2} \mathrm{~K}$

$\dot{W} \quad$ work flow rate, $\mathrm{kJ} / \mathrm{s}$

\section{Greek symbols}

$\eta_{\text {motor }}$ pump electric motor efficiency, $\%$

$\eta_{\text {pump }}$ pump efficiency, $\%$

$\rho \quad$ working fluid density, $\mathrm{kg} / \mathrm{m}^{3}$

\section{INTRODUCTION}

The thermal power plants based on internal combustion engines (ICE) in Brazil, in its majority, were projected to operate seasonally as peaking powers plants (Morawski et al., 2017). Moreover, these power plants were designed under low initial cost and not taking advantage of thermal residues
(Morawski, 2016). In the last years, the worsening of the hydrological conditions and increase of droughts caused the reduction of hydroelectric power output (FUNDAJ, 2019) and, for this reason, in addition to the reduction of natural gas cost (Petrassi, 2012), these thermoelectric power plants were required to operate more often in order to guarantee a safe electrical energy production on the grid, hence, the need for improving the operational availability and efficiency of these thermoelectric power plants arose as consequence of this scenario.

Internal combustion engines are thermal machines that present technical limitations under harsh climatic conditions, such as high temperature and excessive humidity. These climatic conditions decrease the air density, affecting the shaft power, fuel consumption and efficiency, and, consequently, the ICEs performance (Santoianni, 2015). Additionally, these conditions can cause knocking in the engine, harming its mechanical internal parts. Usually, in order to avoid the knocking effect, the Wärtsilä control system limits the engine brake power output by reducing the brake mean effective pressure when the combustion air temperature, before the charge air cooler, exceeds $45^{\circ} \mathrm{C}$ (Wärtsilä, 2008), causing derating. 
The thermal power plants powered by ICEs utilize only part of the fuel energy to develop work on the engine shaft and, consequently, electrical energy. The rest is wasted through exhaust gases, cooling system and convection and radiation of the engine (Domingues, 2011), which motivate the use of systems to recovery the wasted heat in these power plants. Among various alternatives for waste heat recovery (WHR) system, an absorption chiller can be utilized to recover heat, producing chilled water for intake air conditioning.

The intake air cooling and dehumidification in ICE causes the increase of the intake air density, resulting in an increment in admission air and subsequently in the fuel, thus enabling the enhancement of electric power output without the occurrence of the derating due to the knocking phenomenon, moreover, avoiding the formation of condensed water in the air collector. The R\&D Project ANEEL PD-6483-0318/2018 intends to implement an experimental thermal system at the Luiz Oscar Rodrigues de Melo Thermoelectric Power Plant (UTE LORM), located in the city of Linhares, state of Espírito Santo, Brazil, to evaluate the performance improvement of a large internal combustion engine through the intake air conditioning using chilled water produced by a single-effect absorption chiller.

Initially, for this $R \& D$ project, the intention was to use a single-effect absorption chiller, powered by hot water, to cool and dehumidify the intake air to $12.5^{\circ} \mathrm{C}$ with relative humidity $(\mathrm{RH})$ of $100 \%$ in a cooling coil and, also, to provide additional cooling capacity to reduce the engine cooling water temperature using a radiator auxiliary heat exchanger, in order to decrease the combustion air temperature in the charge air cooler (Chun et al., 2019 and Miotto et al., 2020). Simulations using GT-POWER software, presented in Miotto et al. (2020), showed that under these cooled and dehumidified air conditions, the turbocharged Wärtsilä 20V34SG engine can produce an additional power output of $1,445 \mathrm{~kW}$.
However, due to economic circumstances, mainly the increase in the dollar exchange rate, the resources for the project have become more restricted for the initial configuration. Then, alternatives to meet the new economic requirements of the project have been studied.

Due to the fact that the chiller was the most expensive equipment, an alternative thermal design has been developed to use chilled water only on the cooling coil for intake air conditioning, aiming to reduce the chiller capacity. At the same time, instead of using chilled water at the auxiliary heat exchanger, the cooling water from the cooling tower is used to provide alternative cooling effects in the radiator auxiliary heat exchanger. This is a strategic decision because it would reduce the cooling tower sizing, requesting lesser amount of make-up water. It is essential to note that in the initial configuration using chilled water in the auxiliary heat exchanger, the make-up water mass flow was considerably significant, meaning in an undesirable increase in the operating cost for the power plant.

Therefore, this work aims to present a comparison between the initial design proposed in previous works and this alternative one, in order to demonstrate the changes, mainly in thermal design parameters and in investment costs. Furthermore, an economic analysis for both systems, using feasibility indicators (net present value, internal rate of return and payback period), are presented and compared, based on two commercial proposals from the same company, related to the total investment costs.

\section{THE EXPERIMENTAL SYSTEM}

The power plant is composed of 24 generator sets and each one of them presents a turbocharged Wärtsilä 20V34SG engine of $8.7 \mathrm{MW}$ of nominal shaft power, fueled by natural gas, and a Cummings AvK DIG $167 \mathrm{~g} / 10$ generator with $10,549 \mathrm{kVA}$ nominal power that generates $8.545 \mathrm{MW}$ of electrical power, with specific fuel consumption of $166.1 \mathrm{~g} / \mathrm{kWh}$.

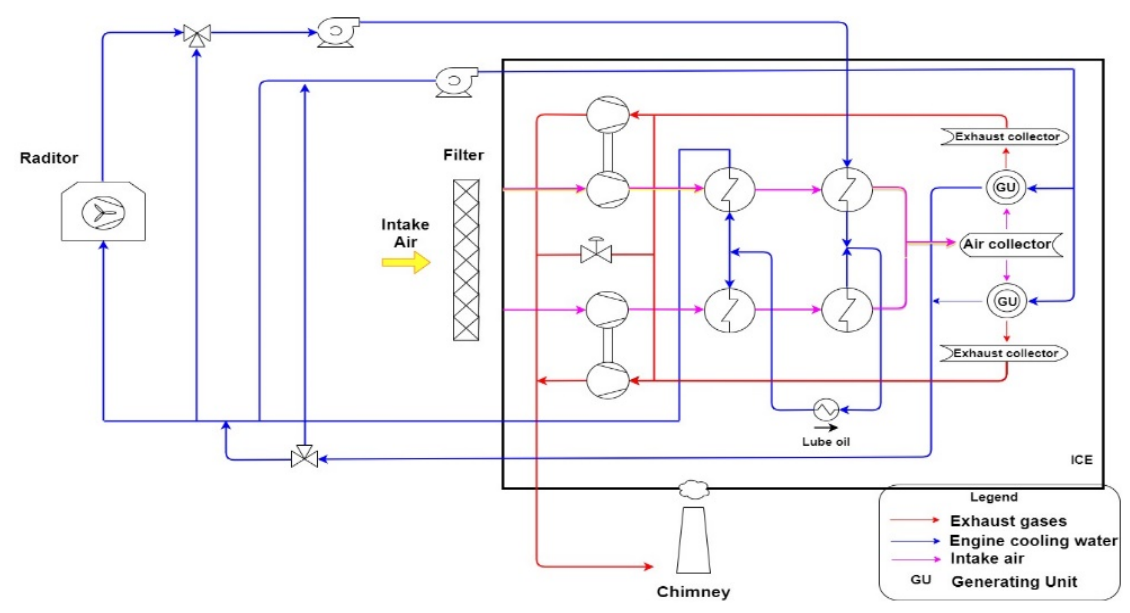

Figure 1. Schematic of one of the current generators sets of the power plant. 
A schematic of the current configuration of the existing generator set at the UTE LORM is showed in Fig. 1, representing the intake air, the exhaust gas and the cooling water systems.

The intake air is admitted after passing through a filter, following to the turbocharger where its compressed to the engine operating pressure. The compressed air is then cooled in the charge air cooler (CAC), using the engine cooling water. The charge air is distributed to the cylinders, and the engine gas collector obtains the exhaust gases from the combustion process inside the cylinders. The pressure in the gas collector depends mainly on engine operation, the turbocharger receives a major part of the exhaust gases. After passing through the turbocharger, the exhaust gases are released into the atmosphere.

The engine cooling system is composed of two water circuits: the high temperature (HT) and the low temperature (LT) water circuits. The HT water circuit is responsible for cooling the set of 20 cylinders in the engine block and the turbocharger, while the LT water circuit cools the air in the intercooler and the lubricating oil. The water temperature control in the high and low temperature circuits takes place through the three-way valves located at the inlet of engine block and at the inlet of the CAC pump, respectively.

The heat added to the cooling system is rejected at the engine radiator, which uses ambient air to reduce the water temperature at the inlet of the CAC inlet down to $2{ }^{\circ} \mathrm{C}$ below the dew-point temperature of the charge air, in order to avoid the condensation of water in the engine intake manifold. The three-way valve of the LT water circuit increases the water temperature in $2^{\circ} \mathrm{C}$ by bypassing enough water, so the outlet water temperature in the radiator must be $4^{\circ} \mathrm{C}$ below the dew-point temperature in the charge air. However, during periods of hot weather, the radiator operates at nominal speed in order to reduce the CAC inlet water temperature to an acceptable value for control purposes. Therefore, the implementation of an auxiliary heat exchanger to supply additional cooling for the engine cooling system would allow a reduction in radiator's power demand (Chun et al., 2019 and Miotto et al., 2020).

Figure 2 illustrates the initial proposed configuration for the WHR thermal system, which consists of an absorption chiller recovering residual heat from the exhaust gases. A heat exchanger uses the heat from the exhaust gases to produce hot water to fuel a single-effect absorption chiller. The chilled water produced in the absorption chiller is used to supply the cooling coil for intake air conditioning. The chilled water is also used in the auxiliary heat exchanger to reduce the temperature of the engine cooling water in order to provide low temperature cooling water for the CAC. A cooling tower was designed to provide cooling water to the absorption chiller only (Chun et al., 2019 and Miotto et al., 2020).

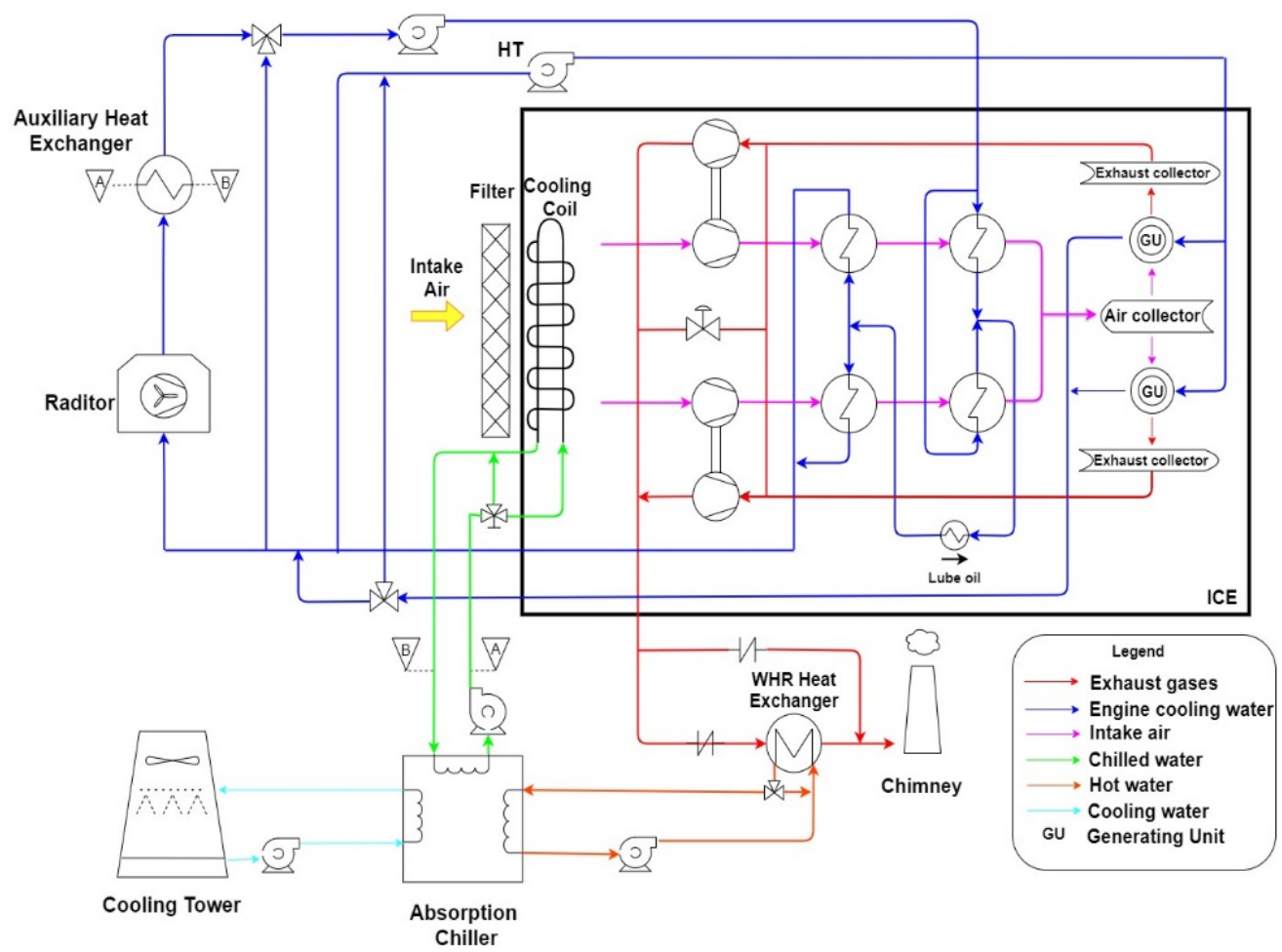

Figure 2. Schematic of the initial design for the WHR system integrated into a generating unit. 
Using climate data collected over the period from January 2018 to January 2020, taken from INMET at climate control station located $34 \mathrm{~km}$ from the thermoelectric plant (INMET, 2020), the chilled water demand can be calculated for the cooling coil and the auxiliary heat exchanger for the first system purpose.

Figure 3 presents the results of the simulations of the first thermal system proposal presented in Miotto et al. (2020) for intake air at $12.5^{\circ} \mathrm{C}$ and $\mathrm{RH}$ of $100 \%$. As shown, the chilled water demand is more prominent for the auxiliary heat exchanger (reaching a peak of $431 \mathrm{RT}$ ).

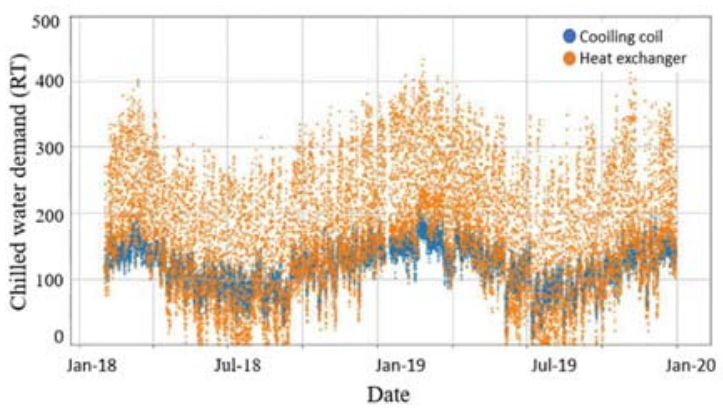

Figure 3. Chilled water demand for the initial configuration of the WHR system.
In contrast, the chilled water demand of the cooling coil reaches levels of 240 RT.

Considering that the chiller is the most expensive equipment in the WHR system, reducing its size is the appropriate way to achieve the required cost reduction of the project. The alternative WHR proposed system, as shown in Fig. 4, uses the chilled water from a singleeffect absorption chiller to supply only the cooling coil, while the cooling tower provides cooling effects for the auxiliary heat exchanger and the absorption chiller. Similar to the initial configuration, the hot water produced by the exhaust gases heat exchanger powers the chiller.

\section{THERMODYNAMIC MODEL}

The thermodynamic modelling of the WHR system was developed in the EES software due to its integrated thermodynamic properties data and the capacity of solving systems. The simplifying hypotheses and parameters were adopted as in Chun et al. (2019) and Miotto et al. (2020), namely: steadystate, adiabatic condition, negligible kinetic and potential energy and constant overall heat transfer coefficient for the heat exchangers.

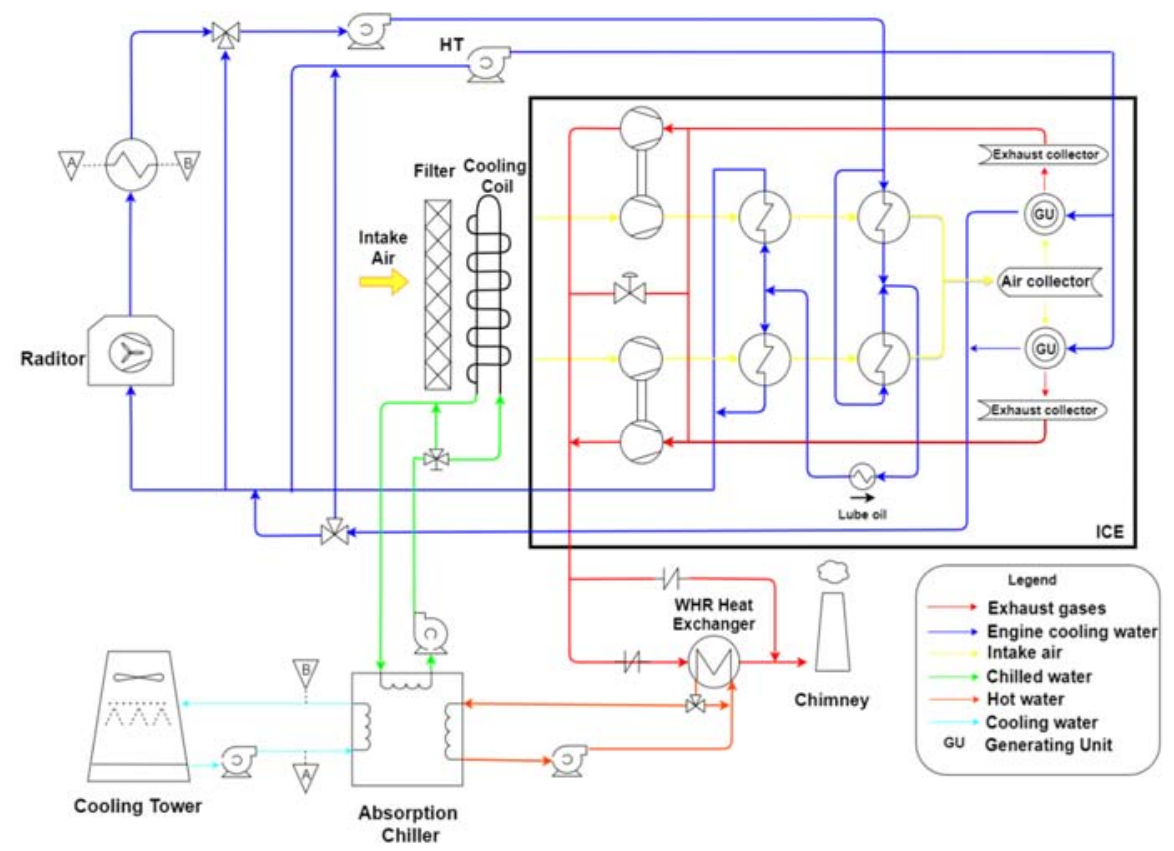

Figure 4. Schematic of the alternative design for the WHR system integrated to a generator set and its auxiliary systems

For each component of the alternative system presented in Fig. 4, mass and energy conservations were applied, as shown in Eq. (1) and Eq. (2), where $m$ is the mass flow rate $(\mathrm{kg} / \mathrm{s}), h$ is the enthalpy $(\mathrm{kJ} / \mathrm{kg})$, $Q$ is the heat flow rate $(\mathrm{kJ} / \mathrm{s}), W$ is work flow rate $(\mathrm{kJ} / \mathrm{s})$ and the subscripts $i$ and $o$ refer to the input and the output of the components, respectively.

$$
\begin{aligned}
& 0=\sum_{i} \dot{m}_{i}-\sum_{o} \dot{m}_{o} \\
& 0=\dot{Q}-\dot{W}+\sum_{i} \dot{m}_{i} h_{i}-\sum_{o} \dot{m}_{o} h_{o}
\end{aligned}
$$


The alternative design system, as shown in Fig. 4, is composed of two heat exchangers: the auxiliary heat exchanger for the radiator and the exhaust gas heat exchanger.

The modelling of the auxiliary heat exchanger was developed according to previous works (Miotto et al., 2020 and Chun et al., 2019). The heat exchanger is considered as a counterflow heat exchanger, where the inlet and outlet cooling system water temperatures are designed as 46 and $33^{\circ} \mathrm{C}$, respectively. However, differently from earlier works, the inlet and outlet of the cold stream in the auxiliary heat exchanger were changed to represent the cooling water from the cooling tower $\left(30\right.$ and $\left.36^{\circ} \mathrm{C}\right)$, instead of the chilled water provided by the chiller $\left(12.6\right.$ and $\left.7^{\circ} \mathrm{C}\right)$. A fixed overall heat transfer coefficient of $1 \mathrm{~kW} / \mathrm{m}^{2} . K$ was adopted, based on typical values for heat exchangers and fluid combination (Incropera et al., 2011).

The modelling of the exhaust gases heat exchanger remains the same as in preceding works (Miotto et al., 2020 and Chun et al., 2019), the gas enters at approximately $390^{\circ} \mathrm{C}$ and the hot water temperatures were fixed at 88 and $98^{\circ} \mathrm{C}$ according to the commercial proposal's chiller. The molar compositions of the natural gas and dry air were maintained the same as in Chun et al. (2019). The gas inlet and outlet temperatures were calculated based on the necessary heat flow to supply the absorption chiller and the energy balance from engine available in Wärtsilä brochure (Wärtsilä, 2008), considering a constant coefficient of performance for the chiller (0.7). The fixed overall heat transfer coefficient of $0.05 \mathrm{~kW} / \mathrm{m}^{2} . K$ is also based on typical values for heat exchangers and fluid combination (Incropera F. P. et al., 2011).

For the calculation of heat flow areas in the auxiliary heat exchanger and the exhaust gas heat exchanger, the logarithmic mean temperature difference (LMTD) method was applied, as shown in Eq. (3). Where $\dot{Q}$ is the heat flow rate $(W), A$ is the heat flow area $\left(\mathrm{m}^{2}\right), U$ is the overall heat transfer coefficient $\left(W / m^{2} . K\right)$.

$$
\dot{Q}=U . A . L M T D
$$

The logarithmic mean temperature difference (LMTD) is calculated by Eq. (4), where $T_{h i}$ and $T_{h o}$ are the hot fluid inlet and outlet temperatures $(K)$ respectively and $T_{c i}$ and $T_{c o}$ are the cold fluid inlet and outlet temperatures $(K)$ respectively.

$$
L M T D=\frac{\left(T_{h i}-T_{c o}\right)-\left(T_{h o}-T_{c i}\right)}{\ln \frac{\left(T_{h i}-T_{c o}\right)}{\left(T_{h o}-T_{c i}\right)}}
$$

The cooling coil modelling is presented in Stoecker and Jones (1982) and it is based on the heat and mass transfer using potential enthalpy difference method, with a linear discretization of the applied temperatures in 10 increments. The outlet air wet bulb temperature of the cooling coil was considered equal to $12.5^{\circ} \mathrm{C}$ to maintain the simulations results of ICE electric power output provided by Miotto et al. (2020). The water inlet and outlet temperatures were also maintained according to the previous work (7 and 12.6 ${ }^{\circ} \mathrm{C}$ ), as are used in the commercial, since the absorption chiller continues to provide chilled water for the cooling coil. As in Chun et al. (2019) and Miotto et al. (2020), a convection heat transfer coefficient of 3 $\mathrm{kW} / \mathrm{m}^{2} . K$ for the water side and $0.55 \mathrm{~kW} / \mathrm{m}^{2} . K$ for the air side is considered.

The procedure for modelling the absorption chiller was also performed according to Chun et al. (2019) and Miotto et al. (2020), utilizing typical values for water temperature of commercial chillers. However, the dimensioning of cooling capacity should now only supply the energy necessary for air conditioning in the cooling coil. The absorption chiller performance is constant, with a coefficient of performance of 0.7 .

The modelling of the cooling tower was performed according to Stoecker and Jones (1982). The tower is a counter-flow configuration and, again, a linear discretization was applied in 10 elements. It was performed mass and energy balance in each one, taking into account the latent and sensible heats. Typical commercial values of approach and range for commercial cooling tower are considered $4{ }^{\circ} \mathrm{C}$ and $6^{\circ} \mathrm{C}$, respectively.

The WHR system is composed of three pumps: for the chilled water circuit, for the hot water circuit and for the cooling water circuit. Equation (5) calculates the new electrical power demand (Wele, in W) for operating pumps, where $Q$ is the volume flow $(\mathrm{m} / \mathrm{s}), \rho$ is the working fluid density $(\mathrm{kg} / \mathrm{m}), g$ is local gravity acceleration $(\mathrm{m} / \mathrm{s} 2)$ and $H$ is the head $(\mathrm{m})$. The electric motor efficiency, named $\eta_{\text {motor, }}$ is considered $90 \%$ and pump efficiency, expressed by $\eta_{\text {pump}}$, is considered equal to $80 \%$.

$$
\dot{W}_{\text {ele }}=\frac{\rho \cdot g \cdot H \cdot Q}{\eta_{\text {motor }} \cdot \eta_{\text {pump }}}
$$

For radiator modelling, it was used the same procedure described in Miotto et al. (2020), that is, the corrected overall heat transfer coefficient of 22.68 $\mathrm{kW} / \mathrm{m}^{2} . K$ and air mass flow rate of $126.56 \mathrm{~kg} / \mathrm{s}$, which was determined by a set of temperatures and water mass flow measured during the current plant operating. The shaft power was considered equal to $85.4 \mathrm{~kW}$.

The equipment was modeled as a counter-flow heat exchanger and the logarithmic mean temperature difference method was used. The inlet water temperature was determined by the energy balance in the engine, using Eq. (1), Eq. (2) and the ICE manufacturer information (Wärtsilä, 2008). The other equipment's parameters, that is, area of $10,126 \mathrm{~m}^{2}$ and nominal fan rotation speed of $865 \mathrm{rpm}$, were considered based on the radiator's manufacture brochure (Wärtsilä, 2009). 


\section{ECONOMIC FEASIBILITY}

The economic feasibility study was conducted based on two commercial proposals, one for the initial WHR system, developed by Chun et al. (2019) and Miotto et al. (2020), and another for the alternative thermal system. Recent simulations, using GTPOWER software, estimated that, due to the intake air conditioning, the additional power generation is 1,455 $\mathrm{kW}$ and the specific fuel consumption is $164.7 \mathrm{~g} / \mathrm{kWh}$, compared to a specific fuel consumption of 166.1 $\mathrm{g} / \mathrm{kWh}$ for the current power plant. The economic feasibility indicators, namely, net present value (NPV), internal rate of return (IRR) and payback were calculated using the economic conditions parameters in Tab. 1.

The fuel cost was calculated based on the monthly consumption of natural gas at the UTE LORM and natural gas tariffs from BR Distribuidora (2020), resulting in a specific cost for fuel of 0.024 $\mathrm{US} \$ \mathrm{~kg}$. The required rate of return (RRR) is the rate used by the Linhares Generation S.A. (LGSA), the company responsible for UTE LORM. In the same way, operational availability is considered based on the plant's operation history. The electricity cost per unit (CVU) is based on the typical value received during the last year by the company for electric energy price sale.

Table 1. Parameters in economic feasibility analysis.

\begin{tabular}{|c|c|}
\hline RRR - required rate of return (\% per year) & 15 \\
\hline Operating life (years) & 20 \\
\hline CVU - Cost per Unit (US\$/ MWh) & 39.40 \\
\hline Operational availability $(\%$ per year) & 96 \\
\hline Specific Fuel cost $(U S \$ / \mathrm{kg})$ & 0.024 \\
\hline Specific Fuel consumption $(\mathrm{g} / \mathrm{MWh})$ & 164.7 \\
\hline
\end{tabular}

The calculation of the economic indicators used is based on Eq. (6), being $N P V$ the net present value (US\$), $t$ the analyzed period (years), $\mathrm{N}_{\mathrm{t}}$ the net cash inflow-outflows during the period (US\$), $i$ the required rate return $(\%)$, and $I$ the initial investment (US\$).

$$
N P V=\sum_{t=1}^{n} \frac{N_{t}}{(1+i)^{t}}-I
$$

The internal rate of return is also calculated by Eq. (6). The IRR is the rate that makes the net present value equal to zero. The payback $(n)$ is the minimum period, which would return the investment. The investment cost values from commercial proposals for initial and alternative WHR systems are respectively US\$ 975,793.27 and US\$ 659,000.00.

\section{RESULTS AND DISCUSSION}

The alternative design for WHR system must be able to supply the chilled water demand for the cooling coil in order to cool and dehumidify the ambient air down to saturated air at $12.5^{\circ} \mathrm{C}$ of wet bulb temperature, aiming to maintain the additional electric power determined by Miotto et al. (2020). Figure 5 presents the new chilled water demand for the alternative WHR system, using the chilled water produced by the absorption chiller only in the cooling coil.

The new demand for chilled water decreases considerably, when compared to Fig. 3 and the simulations results presented in Miotto et al. (2020), and, consequently, the required cooling capacity of the chiller. The new chilled water demand reaches peaks of approximately $240 \mathrm{RT}$ during the summer, when the wet bulb temperature reaches $27.8^{\circ} \mathrm{C}$, the highest value during the two-year of the historic period analyzed.

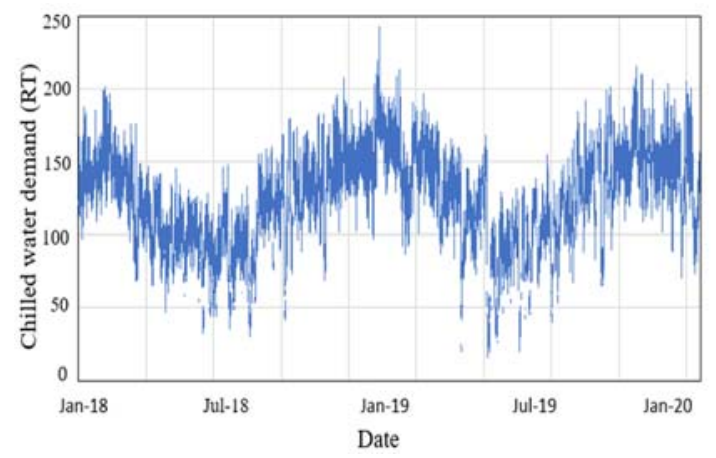

Figure 5. Chilled water demand alternative system.

Figure 6 demonstrates the cumulative frequency curve for the absorption chiller demand and indicates that a $185 \mathrm{RT}(651 \mathrm{~kW})$ absorption chiller would be able to supply the cooling coil during $98.72 \%$ of the period of time. In the initial design, the chiller capacity required to attend $99.54 \%$ of the studied period was $550 \mathrm{RT}(1,934 \mathrm{~kW})$. The variation in attendance period between the two designs is due to the typical commercial capacity values for this equipment.

Table 2 presents a comparison between the main equipment sizing and mass flow rate indicators for the initial WHR system, introduced in the papers (Chun et al., 2019) and (Miotto et al., 2020), and the alternative WHR system. As showed in Tab 2, the new WHR system equipment was reduced in size, except for the auxiliary heat exchanger (due the use of a cooling fluid with a lower temperature difference to the engine cooling fluid), that justifies the smaller investment cost for the new WHR system when compared to the initial proposal, the same applies for the pumps. 


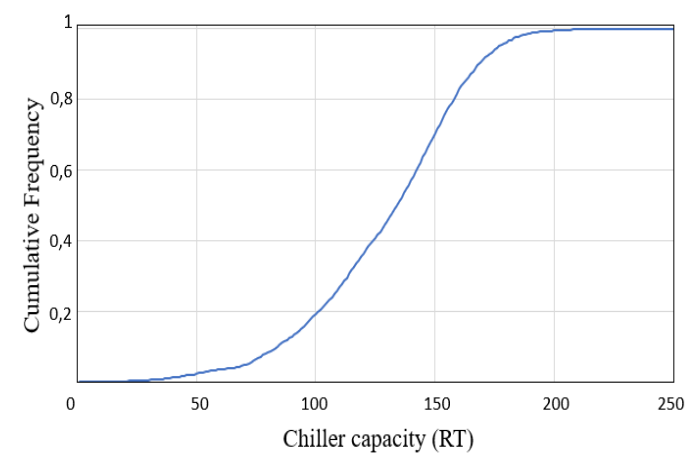

Figure 6. Cumulative frequency versus chiller capacity for the alternative WHR system modeling.

The electric power demanded by each pump in the WHR system and the mass flow rate is presented in Tab. 3. The values must be taken into account for the calculation of WHR system electrical power demand and, therefore, for the economic feasibility.
The required power by the fan at the cooling tower is considered according to the commercial proposals for each WHR system. In the initial proposal, the electrical power demanded is $34 \mathrm{~kW}$, while in the second it is $22 \mathrm{~kW}$ for nominal operation. Additionally, the absorption chillers electrical power demand is $5 \mathrm{~kW}$ for the alternative WHR system and $6.3 \mathrm{~kW}$ for the initial WHR system, also based on the commercial proposals. Therefore, the new total auxiliary electric power consumption of the WHR is $93 \mathrm{~kW}$ and it is lower compared to $170.3 \mathrm{~kW}$ of the initial configuration, i.e., a reduction of $45.38 \%$.

Previous simulations in Miotto et al. (2020) determined an increase of fuel consumption of, approximately, $61.74 \mathrm{~g} / \mathrm{s}$, despite the reduction of specific fuel cost, when compared with the current ICE performance. Therefore, utilizing the operational availability and the specific fuel cost presents in Tab. 2 , an additional plant operating cost can be evaluated as US\$ 44,646.40 per year and this amount is considered in the economic feasibility.

Table 2. Equipment sizing for WHR systems.

\begin{tabular}{|c|c|c|}
\hline Equipment & Initial WHR & Alternative WHR \\
\hline Chiller thermal capacity $(R T)$ & 550 & 185 \\
\hline Cooling tower thermal capacity $(R T)$ & 1,287 & 812 \\
\hline Auxiliary heat exchanger heat flow rate $(\mathrm{kW})$ & 1276.62 & 1276.62 \\
\hline WHR heat exchanger heat flow rate $(\mathrm{kW})$ & 2763 & 928.45 \\
\hline Auxiliary heat exchanger area $\left(\mathrm{m}^{2}\right)$ & 43 & 220 \\
\hline WHR heat exchanger area $\left(m^{2}\right)$ & 243 & 85 \\
\hline Cooling coil area & 856 & 856 \\
\hline Cooling tower water mass flow rate $(\mathrm{kg} / \mathrm{s})$ & 180 & 114 \\
\hline Auxiliary heat exchanger cooling water $(\mathrm{kg} / \mathrm{s})$ & 56 & 51 \\
\hline Chiller cooling water $(\mathrm{kg} / \mathrm{s})$ & 46 & 63 \\
\hline
\end{tabular}

Table 3. Pump consumption for the initial alternative WHR systems.

\begin{tabular}{|c|c|c|c|c|}
\hline \multirow{2}{*}{} & \multicolumn{2}{|c|}{ Initial WHR system } & \multicolumn{2}{c|}{ Alternative WHR system } \\
\cline { 2 - 5 } & Pump power $(\mathrm{kW})$ & Mass flow rate $(\mathrm{kg} / \mathrm{s})$ & Pump power $(\mathrm{kW})$ & Mass flow rate $(\mathrm{kg} / \mathrm{s})$ \\
\hline Hot water & 27 & 64 & 10 & 22 \\
\hline Chilled water & 31 & 82 & 11 & 28 \\
\hline Cooling water & 72 & 180 & 45 & 114 \\
\hline
\end{tabular}

Therefore, since in the alternative WHR system the intake air condition could be maintained, the additional power of $1,445 \mathrm{~kW}$ would also be obtained, as in the initial WHR system. Thus, taking into account the WHR systems electric power demand, the alternative design plant generates $1,352 \mathrm{~kW}$ of additional power, i.e., an increment of $77.3 \mathrm{~kW}$ in comparison with $1,274.7 \mathrm{~kW}$ of additional power calculated for the initial WHR system, according to the commercial proposals.

The preliminary analysis of the economic viability can then be performed. Table 4 presents the economic indicators NPV, IRR and payback period for the implementation of the thermal system, considering the investment costs of each proposal.

The alternative WHR system proposal presents higher NPV (US\$469,107.06 of additional profit), shorter time for capital recovery (payback period of 2.14 years) and higher IRR of $58.28 \%$ when compared to the IRR of the initial system, of $36.80 \%$, while also presenting lower initial investment cost, proving to be the best investment.

Table 4 - Economic indicators.

\begin{tabular}{|c|c|c|}
\hline WHR systems & Initial & Alternative \\
\hline NPV (US\$) & $1,276,154.06$ & $1,745,261.12$ \\
\hline Payback (years) & 3.75 & 2.14 \\
\hline IRR (\%) & 36.80 & 58.28 \\
\hline
\end{tabular}

\section{FINAL REMARKS AND OUTLOOKS}

This work presents an alternative design for the waste heat recovery (WHR) system for one of the generators sets of Luiz Oscar Rodrigues de Melo 
Thermoelectric Power Plant, using ambient condition data provided by a weather station nearby the UTE LORM, with the intent of reducing the investment cost for the system, when compared with the initial system present in Chun et al. (2019) and Miotto et al. (2020). Also, economic viability analysis for both systems are compared based on confidential economic proposals for the WHR system implementation.

The dimensioning of the necessary chiller cooling capacity determined that $185 \mathrm{RT}(651 \mathrm{~kW})$ would be sufficient to supply the chilled water demand of $98.72 \%$ of the analyzed period, i.e., a significant reduction of $365 \mathrm{RT}(1,236 \mathrm{~kW})$ in the installed capacity when compared to the absorption chiller determined in previous works of $550 \mathrm{RT}(1,934 \mathrm{~kW})$.

The power demand of the alternative WHR system is $93 \mathrm{~kW}$, taking into account the power demand of the chilled water pump, hot water pump, the cooling water pump (cooling tower) and the additional demand required for the cooling tower fans and chiller auxiliary power, according to the calculations and commercial proposals. Therefore, since in the alternative WHR system the intake air condition could be maintained, the additional power output of $1,445 \mathrm{~kW}$ as in Miotto et al. (2020) is considered. Thus, the alternative design plant generates $1,352 \mathrm{~kW}$ of additional power, an increment of $77.3 \mathrm{~kW}$ in comparison with $1,274.7 \mathrm{~kW}$ of additional power due to the reduction on the power consumption.

The preliminary economic viability study was conducted based on two commercial proposals for implementing the thermal system. The alternative WHR system proposal is shown as the best investment alternative according to the economic indicators utilized, presenting a lower investment cost (US\$316,793.27 of savings), with US\$ 469,107.06 of additional profit (greater NPV), a higher IRR $(58.28 \%)$ and a time for capital recovery of 2.14 years, 1.61 years shorter when compared with the initial WHR system.

Despite the economic advantages of the alternative system, in periods of low demand of intake air conditioning, the original configuration could save more power in the radiator than this alternative proposal due to colder fluid stream in the auxiliary heat exchanger $\left(7\right.$ and $\left.12.6^{\circ} \mathrm{C}\right)$ when compared to the alternative design $\left(30\right.$ and $\left.36^{\circ} \mathrm{C}\right)$.

In future works, the installation and experimental testing of the alternative system will provide more realistic investment values and energy gains. Through these values, the final analysis of economic feasibility will be conducted. Additionally, the analysis can be updated with potential new commercial proposals.

\section{ACKNOWLEDGMENTS}

The authors would like to thank the Thermoelectric Viana S.A. (TEVISA) and Linhares Generation S.A. (LGSA) for sponsoring the R\&D Project ANEEL PD-
06483-0318/2018 and the Coordination for the Improvement of Higher Education (CAPES) for financial support.

\section{REFERENCES}

Bergman, T. L., Lavine, A. S., Incropera, F. P. and Dewitt, D. P., 2011, Fundamentals of Heat and Mass Transfer, John Wiley \& Sons, 7 th edition.

BR DISTRIBUIDORA, 2020, Tarifas, $<\mathrm{http}$ ://www.br.com.br/pc/produtos-e-servicos/gasnatural/tarifas $>$.

Chun, A., Miotto, B. M. F., Krohling, G. S., Paulo, L. A., Spacini, K., Cunha, C. C. M., Santos, J. J. C. S. and Donatelli, J. L. M., 2019, Dimensionamento da capacidade térmica de um sistema experimental de recuperação de calor residual para o condicionamento do ar de admissão de um motor de combustão interna de grande porte, in: Proceedings of the XIV Congreso Iberoamericano de Ingeniería Mecánica, Cartagena de Indias, Colombia.

Domingues, A., 2011, Avaliação do potencial de aproveitamento da energia contida nos gases de escape de automóveis, Master's Thesis, Universidade Técnica de Lisboa, Lisboa, Portugal.

FUNDAJ, 2020, Pouca chuva leva hidrelétricas a menor nível desde 2014, Joaquim Nabuco Foundation, $<$ https://www.fundaj.gov.br/index.php/a-questaoenergetica/11612-pouca-chuva-leva-hidreletricas-amenor-nivel-desde-2014>.

INMET, 2020, Consulta Dados da Estação Automática: Linhares (ES), Instituto Nacional de Meteorologia, <http://www.inmet.gov.br/sonabra/pg _ dspDados Codigo_sim.php?QTYxNA $>$.

Miotto, B. M. F., Chun, A., Santos, J. J. C. S., Donatelli, J. L. M., Cunha, C. C. M. and Zabeu, C. B., 2020, Simulation of a WHR system integrated with a large internal combustion engine for intake air conditioning using variable climate data and engine performance, in: Proceedings of the 33rd International Conference on Efficiency, Cost, Optimization, Simulation and Environmental Impact of Energy Systems - ECOS 2020, Osaka, Japan.

Morawski, A. P., Cunha, C. C. M., Sena, C. J., Donatelli, J. L. M. and Santos, J. J. C. S., 2017, Repotenciação da UTE Viana por meio do aproveitamento do calor rejeitado, in Anais do IX Congresso de Inovação Tecnológica em Energia Elétrica - CITENEL 2017, João Pessoa, Brazil.

Petrassi, P., 2012, Relatório do Ensaio de Desempenho Usina Termelétrica Luiz Oscar Rodrigues de Melo, Technical Report, Linhares, Brazil.

Santoianni, D., 2015, Power plant performance under extreme ambient conditions, Technical Report No.: J 2015: 22-27, Wärtsilä, Finland.

Stoecker, W. F. and Jones, J. W., 1982, Refrigeration and air conditioning, McGraw-Hill.

Wärtsilä, 2008, Wärtsila 34SG Power Plant Product Guide, Wärtsilä, Finland. 
Wärtsilä, 2009, Air blast cooler type RKDH, OEM Manual, Technical Report. Document No. DBAB552449, Linhares, Brazil. 